Intermediate Statistics for

Geographers and Earth Scientists 
Other Macmillan titles of related interest

R. Till, Statistical Methods for Earth Scientists

R. B. G. Williams, Introduction to Statistics for Geographers and Earth Scientists (companion volume)

\section{Associated software}

T. J. Browne and R. B. G. Williams, STATCALC 


\title{
Intermediate Statistics for \\ Geographers and Earth Scientists
}

\author{
R. B. G. Williams \\ University of Sussex \\ Brighton
}

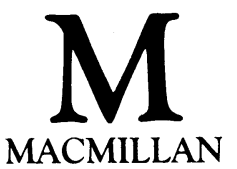


All rights reserved. No reproduction, copy or transmission of this publication may be made without written permission.

No paragraph of this publication may be reproduced, copied or transmitted save with written permission or in accordance with the provisions of the Copyright Act 1956 (as amended).

Any person who does any unauthorised act in relation to this publication may be liable to criminal prosecution and civil claims for damages.

First published 1986

Published by

MACMILLAN EDUCATION LTD

Houndmills, Basingstoke, Hampshire RG21 2XS

and London

Companies and representatives

throughout the world

\section{British Library Cataloguing in Publication Data}

Williams, R.B.G.

Intermediate statistics for geographers and

earth scientists.

1. Earth sciences-Statistical methods

I. Title

519.5'02455 QE33.2.M3

ISBN 978-0-333-35274-8

DOI 10.1007/978-1-349-06813-5

ISBN 978-1-349-06813-5 (eBook)

ISBN of associated software: 978-0-333-39598-0 


\section{Contents}

Preface vii

Acknowledgements ix

21 Single Factor Analysis of Variance 351

22 Two-factor and Multi-factor Analysis of Variance 380

23 Nested and Split-plot ANOVAs 404

24 ANOVA and Regression Analysis $\quad 425$

25 The Point Biserial and Phi Coefficients of Correlation 441

26 Spearman's and Kendall's Coefficients of Rank Correlation 451

27 The Effects of Major Violations of the Assumptions of the Linear Regression Model 480

28 The Zero Intercept, Major Axis and Reduced Major-axis Regression Lines 531

29 Curvilinear Regression 554

30 Multiple Linear Regression and Correlation 596

31 Analysis of Covariance 630

32 The Use and Abuse of Statistical Techniques 664 Statistical Tables $\quad 694$

References $\quad 702$

Further Reading $\quad 707$

Index 709 


\section{Preface}

The present work is offered as a companion to "Introduction to Statistics", which was published in 1984. It explains more advanced statistical techniques than its predecessor, including analysis of variance, curvilinear and multiple regression, and covariance analysis. Numerous worked examples are provided which are drawn from the fields of geography, planning and the earth sciences. The final chapter discusses some of the more controversial aspects of statistics, in particular the logic of significance testing.

Although this book is a continuation of "Introduction to Statistics", it can be read quite independently by anyone with a knowledge of the basic techniques of statistics. The text was originally developed as background reading for a course at the University of Sussex, and has been much modified as a result of experience of teaching the subject. Only a limited knowledge of mathematics is required. It is hoped that the book will be found useful for both class teaching and private study.

I should like to acknowledge my indebtedness to the many friends who have given advice and help, in particular my colleagues, Dr. D.C. Funne11, Dr. T.J. Browne, and Mr. M.F. Dunford. Miss Susan Rowland has provided invaluable assistance turning my crude drawings into finished diagrams. My special thanks are due to my wife, Elizabeth, who has been a constant source of help and encouragement. She has had to live with the writing of this book for far too long.

I am most grateful to readers of "Introduction to Statistics" who have written to me with suggestions and corrections. I hope that readers of the present book will also call my attention to any errors and imperfections that they note.

Software programs that implement many of the statistical techniques discussed in this book are available on disc for the BBC microcomputer. These programs are written in BASIC and are fully listable. In contrast to this book, the emphasis of the programs is on carrying out calculations rather than explaining the techniques. The programs assume that users are sufficiently familiar with the techniques to decide which ones are appropriate for analysing their particular data sets, and also are knowledgeable enough to interpret the results of the analyses. All the programs have been tested and run successfully on a wide range of research data.

University of Sussex

June 1985 


\section{Acknowledgements}

The author and publishers wish to thank the following who have kindly given permission for the use of copyright material:

Blackwell Scientific Publications Ltd for extract Environmental determinants of island species numbers in the British Isles by M P Johnson and D S Simberloff from The Journal of Biogeography (1974).

W H Freeman and Company, Publishers, for extracts from 'Steins paradox in Statistics' by Efron and Morris in Scientific American Vol 236, No 5, May 1977.

Dr C Funnell for permission to use unpublished data.

The Controller of Her Majesty's Stationery office for table from Report on the Census of Distribution and other services, Department of Industry.

Institute of British Geographers for extract, 'Suspended sediment delivery rates and the solute concentration of stream discharge in two Welsh catchments' by $\mathrm{N}$ C Oxley from Fluvial Processes in

Instrumented Watersheds.

Dr A S Potts for permission to use published data.

Dr E A Potts for permission to use data from her unpublished PhD thesis.

John Wiley \& Sons Inc. for tables from Practical Nonparametric Statistics by Canover and the Biometrika Trust.

Every effort has been made to trace all the copyright holders but if any have been inadvertently overlooked the publishers will be pleased to make the necessary arrangement at the first opportunity. 
The pagination follows on from "Introduction to Statistics", as does the chapter numbering. The series of statistical tables is also continued with Tables $N$ to $R$. Table $G$ from the earlier book is included because it is much needed for analysis of variance. The other tables have not been repeated owing to limitations of space. 